\title{
Marinifilum fragile gen. nov., sp. nov., isolated from tidal flat sediment
}

Correspondence
Jongsik Chun
jchun@snu.ac.kr

\author{
Hyunsoo Na, Seil Kim, Eun Young Moon and Jongsik Chun
}

School of Biological Sciences, Seoul National University, Shillim-dong, Kwanak-gu, Seoul 151-742, Republic of Korea

\begin{abstract}
A facultatively anaerobic, moderately halophilic, Gram-negative, filamentous bacterium, designated $\mathrm{JC} 469^{\top}$, was isolated from tidal flat sediment in Korea. Phylogenetic analysis based on $16 \mathrm{~S}$ rRNA gene sequences showed that the isolate belonged to the phylum Bacteroidetes and its closest taxonomic relative was Cytophaga fermentans NCIMB $2218^{\top}$ ( $89.6 \%$ sequence similarity). Cells appeared as filaments during exponential growth, but became fragmented to rods at stationary phase. Spherical cells were also observed in aged cultures. Strain $\mathrm{JC}_{2} 469^{\top}$ contained iso- $\mathrm{C}_{15: 0}(56.2 \%)$ and $\mathrm{MK}-7$ as the predominant fatty acid and respiratory quinone, respectively. On the basis of evidence from this polyphasic study, the isolate showed substantial differences from other genera. The phylogenetic and physiological data of the present study strongly suggest that the isolate represents a novel genus and species, for which the name Marinifilum fragile gen. nov., sp. nov. is proposed. The type strain of Marinifilum fragile is JC2469 ${ }^{\top}$ $\left(=\right.$ IMSNU $14138^{\top}=$ KCTC $\left.22488^{\top}=\mathrm{JCM} 15579^{\top}\right)$.
\end{abstract}

Tidal flats have been shown to harbour highly diverse strains of bacteria (Kim et al., 2004, 2005). During the study on culturable bacteria from a tidal flat in Korea, a novel bacterial strain, designated $\mathrm{JC} 2469^{\mathrm{T}}$, was isolated from a tidal flat sediment sample from Yeocha, Ganghwa Island, South Korea (37 $37^{\prime} \mathrm{N} 126^{\circ} 22^{\prime}$ E). Following inoculation, enrichment was carried out in modified DSMZ medium 198 supplemented with $3.7 \mathrm{mM}$ sodium acetate, incubated anaerobically at $30{ }^{\circ} \mathrm{C}$. A pure culture of strain $\mathrm{JC} 2469^{\mathrm{T}}$ was obtained via serial dilution and plating on marine agar 2216 (MA; Difco) plates. As the isolate also showed growth under aerobic conditions, it was routinely cultivated aerobically on MA at $30{ }^{\circ} \mathrm{C}$. Cultures were stored as glycerol suspensions $(20 \%, \mathrm{v} / \mathrm{v})$ at $-85^{\circ} \mathrm{C}$.

DNA extraction, PCR amplification and sequencing of the 16S rRNA gene were carried out as described previously (Chun \& Goodfellow, 1995). The identification of phylogenetic neighbours was initially carried out using BLAST (Altschul et al., 1997) and FASTA (Pearson \& Lipman, 1988) against the database of prokaryotic type strains with validly published names using the EzTaxon server (Chun et al., 2007). A preliminary similarity search indicated that our isolate belonged to the phylum Bacteroidetes. Alignment and phylogenetic analyses were carried out using jPHYDIT (Jeon et al., 2005) and PAUP version 4.0 (Swofford, 1998) as described previously (Kim, et al., 2005; Yi \& Chun, 2006a). Phylogenetic trees were constructed according to the Fitch-Margoliash (Fitch \& Margoliash,

The GenBank/EMBL/DDBJ accession number for the 16S rRNA gene sequence of strain $\mathrm{JC} 469^{\top}$ is FJ394546.
1967), maximum-likelihood (Felsenstein, 1981), maximum-parsimony (Fitch, 1971) and neighbour-joining (Saitou \& Nei, 1987) methods. Pairwise evolutionary distances were computed according to the model of Jukes \& Cantor (1969). Branch stability was evaluated by 1000 neighbour-joining replications (Felsenstein, 1985).

The results of a comprehensive phylogenetic analysis are shown in Fig. 1. On the basis of $16 \mathrm{~S}$ rRNA gene sequence similarities, the closest relative was Cytophaga fermentans NCIMB $2218^{\mathrm{T}}(89.6 \%)$, followed by Alkaliflexus imshenetskii Z-7010 ${ }^{\mathrm{T}}(87.9 \%)$, Prolixibacter bellariivorans $\mathrm{F} 2^{\mathrm{T}}$ (86.3\%), Paludibacter propionicigenes $\mathrm{WB}^{\mathrm{T}}(86.0 \%)$, Zhouia amylolytica $\mathrm{HN}-171^{\mathrm{T}}(85.6 \%)$, Aequorivita antarctica SW49 ${ }^{\mathrm{T}}(84.9 \%)$ and Actibacter sediminis $\mathrm{JC} 2129^{\mathrm{T}}$ $(84.4 \%)$. Strain JC2469 ${ }^{\mathrm{T}}$ formed a monophyletic clade with C. fermentans NCIMB $2218^{\mathrm{T}}$, though it was weakly supported, with a bootstrap value of $46 \%$.

The Gram reaction was checked by standard Gram staining (Difco) and KOH tests (Powers, 1995). Cell morphology was examined by phase-contrast (Axioskop 40; Zeiss), scanning electron (JSM-5410LV; JEOL) and energy-filtering transmission electron (Libra 120; Zeiss) microscopes using 2-, 7- and 12-day-old cultures grown on MA at $30{ }^{\circ} \mathrm{C}$. Motility was examined on semi-solid MA medium after incubation at $30{ }^{\circ} \mathrm{C}$ for $24 \mathrm{~h}$. Gliding motility was checked by direct microscopic examination of the edges of colonies during exponential growth on MA, as described previously (Yi \& Chun, 2006b). Heat resistance was examined by heating 2- or 3-week-old spherical cellcontaining cultures at $80{ }^{\circ} \mathrm{C}$ for $10 \mathrm{~min}$. Desiccation 


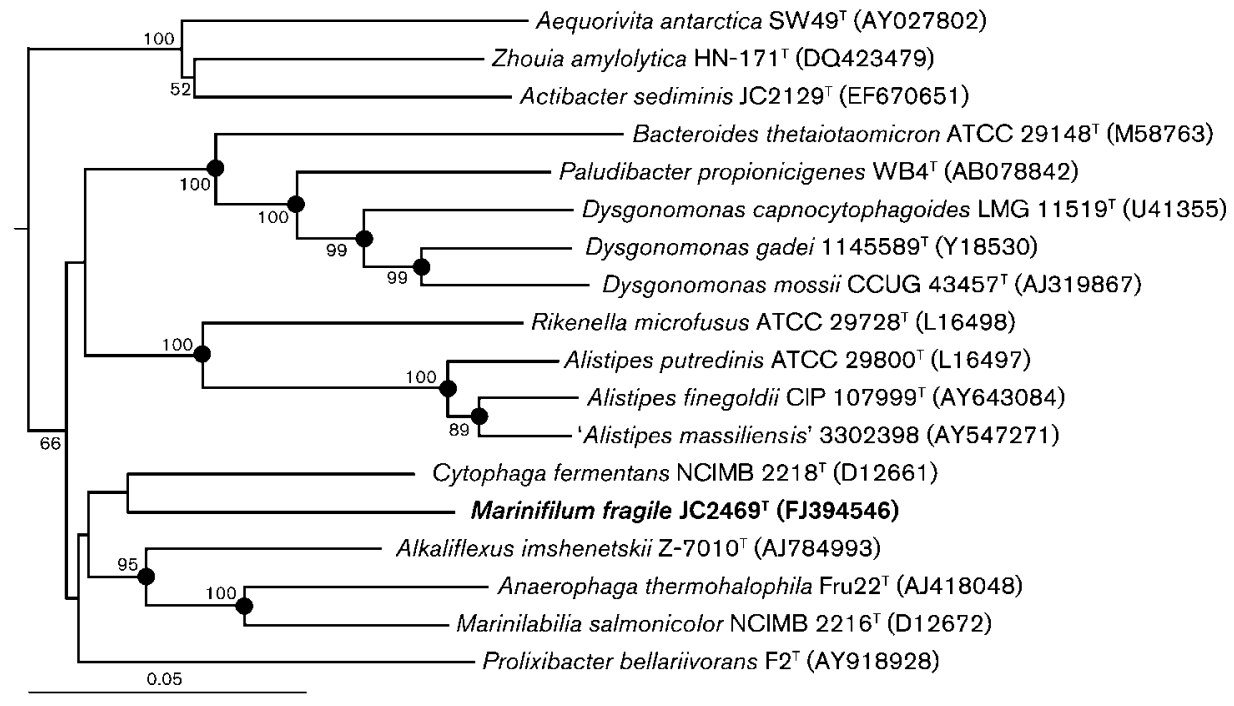

Fig. 1. Neighbour-joining tree based on $16 \mathrm{~S}$ rRNA gene sequences showing the phylogenetic position of strain $\mathrm{JC}^{2469}{ }^{\top}$ among related species of the phylum Bacteroidetes. Bootstrap values $(>50 \%)$ are shown at branch nodes. Solid circles indicate that the corresponding nodes are also recovered in Fitch-Margoliash, maximum-likelihood and maximum-parsimony trees. The sequence of Haliscomenobacter hydrossis DSM $1100^{\top}$ (GenBank accession no. AJ784892) was used as the outgroup (not shown). Bar, 0.05 substitutions per nucleotide position.

resistance was assessed as described by Wise et al. (2001). Growth under different conditions with a temperaturegradient incubator (TVS126MA; Advantec) was monitored by measuring the optical density at $600 \mathrm{~nm}$. Growth was evaluated at various temperatures $(10,16,20,24,27,30$, $34,37,41,45,49$ and $55^{\circ} \mathrm{C}$ ) in marine broth. Growth at

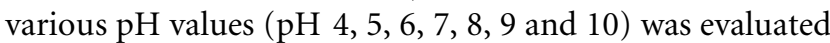
in marine broth adjusted with $6 \mathrm{M} \mathrm{HCl}$ or $10 \mathrm{M} \mathrm{KOH}$. Salt requirement and tolerance were determined in ZoBell medium (Yi \& Chun, 2006b) with artificial sea salts (Sigma) or $\mathrm{NaCl}(0,1,3,5,7$ and $9 \%, \mathrm{w} / \mathrm{v})$.

Cells of strain JC2469 ${ }^{\mathrm{T}}$ were Gram-negative, non-motile and non-gliding. Endospore formation was not observed throughout the entire phase of growth. Cells were filamentous during exponential growth, and then fragmented into rods (Fig. 2a, b). They later became spherical during the stationary phase. A similar morphological transition has been reported for Alkaliflexus imshenetskii, one of the isolate's phylogenetic neighbours (Zhilina et al., 2004). The filaments and rods were generally $0.5 \mu \mathrm{m}$ wide and variable in length. Transmission electron microscopy showed a $0.3-3.8 \mu \mathrm{m}$ long flagella-like structure at the end of filaments (Fig. 2c), despite the fact that we were not able to find motile cells under light microscopy and the cells gave a negative result for the motility test based on semisolid media. Ultrathin sections often exhibited bud-like cells at the end of the filaments (Fig. 2f). Our isolate was sensitive to heat and did not survive 1 week of desiccation. Colonies on MA plates appeared circular, in some cases with erose edges, and became ivory to brownish ivory coloured as they grew. Strain JC2469 $9^{\mathrm{T}}$ grew at $20-37.4{ }^{\circ} \mathrm{C}$ (optimum $33{ }^{\circ} \mathrm{C}$ ), at $\mathrm{pH}$ 6-8 (optimum $\mathrm{pH}$ 7) and at 1$7 \%(\mathrm{w} / \mathrm{v})$ artificial sea salt concentration (optimum $3 \%$ ). No growth was observed in the absence of sea salts or with $\mathrm{NaCl}$ alone.

Catalase and oxidase activities were determined using $3 \%$ $(\mathrm{v} / \mathrm{v})$ hydrogen peroxide and Kovács' reagent (Kovács, 1956). Other enzyme activities were tested at $37{ }^{\circ} \mathrm{C}$ using API ZYM, substrate utilization and biochemical tests were carried out at $30{ }^{\circ} \mathrm{C}$ with API $50 \mathrm{CH} \mathrm{B/E}$ and nitrate reduction, indole production and $\mathrm{H}_{2} \mathrm{~S}$ production tests were performed using API 20NE and API 20E (all from bioMérieux). Strain JC2469 ${ }^{\mathrm{T}}$ showed no reaction with the sea-salt-free API $50 \mathrm{CH} \mathrm{B} / \mathrm{E}$ medium. Therefore, the medium was amended with filter-sterilized artificial sea salts at a final concentration of $3 \%$ for strain $\mathrm{JC} 2469^{\mathrm{T}}$ and C. fermentans KCTC $2901^{\mathrm{T}}$. The API tests were performed for strain $\mathrm{JC}_{2469^{\mathrm{T}}}$, C. fermentans KCTC $2901^{\mathrm{T}}$ and Paludibacter propionicigenes JCM $13257^{\mathrm{T}}$. Our isolate showed negative reactions for both catalase and oxidase. The results of biochemical and physiological tests are given in Table 1 and in the genus and species descriptions.

To determine the end products of glucose fermentation, the basal medium (Kim et al., 2007) was slightly modified to contain the following $\left(1^{-1}\right.$ distilled water): $1 \mathrm{~g} \mathrm{NH}_{4} \mathrm{Cl}$, $0.3 \mathrm{~g} \mathrm{~K}_{2} \mathrm{HPO}_{4}, 0.3 \mathrm{~g} \mathrm{KH}_{2} \mathrm{PO}_{4}, 30$ g sea salts, 3.6 g glucose, $0.5 \mathrm{~g}$ cysteine hydrochloride, $0.3 \mathrm{~g} \mathrm{Na} \mathrm{Na}_{2} \mathrm{~S} .9 \mathrm{H}_{2} \mathrm{O}, 1 \mathrm{mg}$ resazurin (Sigma), $1 \mathrm{ml}$ trace mineral element solution (DSMZ medium 318) and $1 \mathrm{ml}$ vitamin solution (DSMZ medium 141). After 3 weeks of incubation at $30{ }^{\circ} \mathrm{C}$, the fermentation end products were analysed with GC (ACME 6000GC; Young Lin) and HPLC (HP1100; Hewlett 


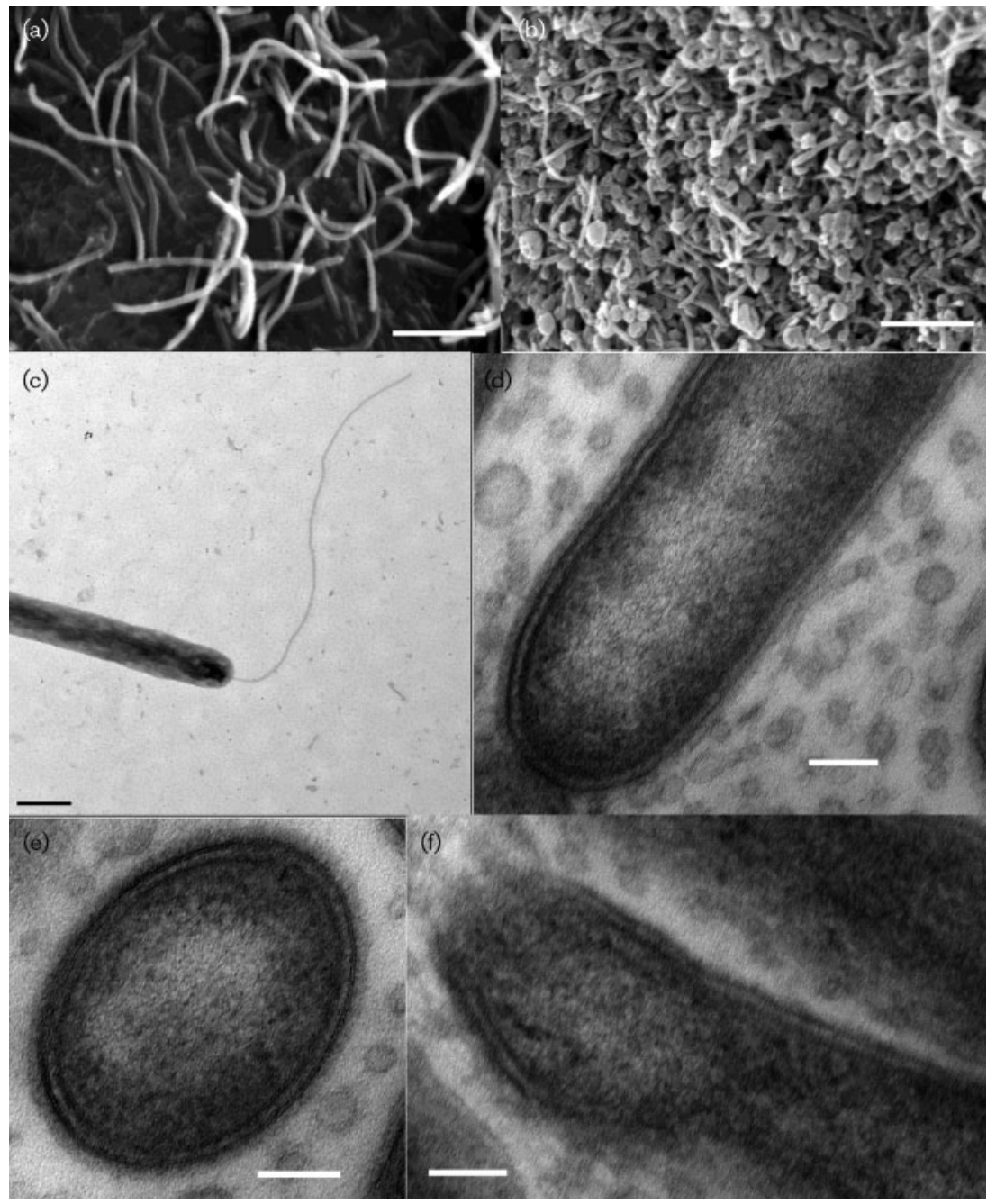

Fig. 2. Electron micrographs of strain JC2469 ${ }^{\mathrm{T}}$ : scanning electron micrographs of cells in the exponential (a) and stationary (b) phases; transmission electron micrograph (c); ultrathin sections revealing the membrane structure of a filament $(d)$ and a spherical cell (e); bud-like structures are often observed at one end of the filament (f). Bars, $5 \mu \mathrm{m}(a, b)$, $0.5 \mu \mathrm{m}$ (c) and $100 \mathrm{~nm}(\mathrm{~d}-\mathrm{f})$.

Packard) as described previously (Kim et al., 2007). The $\mathrm{G}+\mathrm{C}$ content was determined with HPLC of the deoxyribonucleosides as described by Mesbah \& Whitman (1989), using a reversed-phase column (Supelcosil LC-18-S; Supelco). Isoprenoid quinones were extracted from 2-day-old cells grown on MA at $30{ }^{\circ} \mathrm{C}$, according to the method of Minnikin et al. (1984), and analysed by reversed-phase TLC and HPLC as described by Collins (1985). Cellular fatty acids of the test strains were analysed as methyl esters by GC according to the instructions of the Microbial Identification System (MIDI). Fatty acid methyl esters were prepared from biomass grown on $\mathrm{MA}$ at $30{ }^{\circ} \mathrm{C}$ for 2 days.

Strain JC2469 ${ }^{\mathrm{T}}$ produced acetate and propionate as major fermentation products from glucose. The $\mathrm{G}+\mathrm{C}$ content of strain $\mathrm{JC}_{2469^{\mathrm{T}}}$ was $45 \mathrm{~mol} \%$. The major respiratory quinone of $\mathrm{JC}_{2} 469^{\mathrm{T}}$ was $\mathrm{MK}-7$, as also reported for $C$. fermentans (Nakagawa \& Yamasato, 1993), but different from those of Paludibacter propionicigenes (MK-8; Ueki et al., 2006) and Z. amylolytica (MK-6; Liu et al., 2006). The major cellular fatty acids were iso- $\mathrm{C}_{15: 0}(56.2 \%)$, iso-
$\mathrm{C}_{15: 0} 3-\mathrm{OH}(9.1 \%)$, iso- $\mathrm{C}_{17: 0} 3-\mathrm{OH}(7.0 \%)$, iso- $\mathrm{C}_{13: 0}$ $(4.4 \%)$ and anteiso- $\mathrm{C}_{15: 0}(3.5 \%)$. A comparison of the cellular fatty acids of strain $\mathrm{JC} 2469^{\mathrm{T}}$ and its phylogenetic neighbours is shown in Table 2.

Strain JC2469 ${ }^{\mathrm{T}}$ shows very low $16 \mathrm{~S}$ rRNA gene sequence similarity $(<90 \%)$ to its closest neighbours in the phylum Bacteroidetes. Its dramatic morphological transformation during growth is a unique characteristic that can be used to differentiate it from its closest neighbours. Additionally, several other physiological and biochemical characteristics differentiate strain JC2469 $9^{\mathrm{T}}$ from related species (Table 1). On the basis of evidence presented here, it is proposed that the tidal flat isolate be classified in a novel genus in the phylum Bacteroidetes as Marinifilum fragile gen. nov., sp. nov.

\section{Description of Marinifilum gen. nov.}

Marinifilum (Ma.ri.ni.fi'lum. L. adj. marinus belonging to the sea; L. neut. n. filum a thread; N.L. neut. n. Marinifilum a thread belonging to or living in the sea). 
Table 1. Comparison of major features of strain $\mathrm{JC} 469^{\top}$ with its phylogenetic neighbours

Strains: 1, Marinifilum fragile gen. nov., sp. nov. JC2469 ${ }^{\mathrm{T}}$ (data from this study); 2, Cytophaga fermentans KCTC $2901^{\mathrm{T}}$ (unless indicated, data from Reichenbach, 1989); 3, Alkaliflexus imshenetskii DSM $15055^{\mathrm{T}}$ (Zhilina et al., 2004); 4, Prolixibacter bellariivorans JCM $13498^{\mathrm{T}}$ (Holmes et al., 2007); 5, Paludibacter propionicigenes JCM $13257^{\mathrm{T}}$ (Ueki et al., 2006); 6, Zhouia amylolytica JCM $14016^{\mathrm{T}}$ (Liu et al., 2006); 7, Aequorivita antarctica DSM $14231^{\mathrm{T}}$ (Bowman \& Nichols, 2002); 8, Actibacter sediminis JCM 14002 ${ }^{\mathrm{T}}$ (Kim et al., 2008). +, Positive; -, negative; w, weak; ND, not detected/not reported.

\begin{tabular}{|c|c|c|c|c|c|c|c|c|}
\hline Characteristic & 1 & 2 & 3 & 4 & 5 & 6 & 7 & 8 \\
\hline Source of isolation & $\begin{array}{c}\text { Marine } \\
\text { environment }\end{array}$ & $\begin{array}{c}\text { Marine } \\
\text { environment }\end{array}$ & $\begin{array}{r}\text { Soda } \\
\text { lake }\end{array}$ & $\begin{array}{c}\text { Marine } \\
\text { environment }\end{array}$ & Rice field & $\begin{array}{c}\text { Marine } \\
\text { environment }\end{array}$ & $\begin{array}{c}\text { Marine } \\
\text { environment }\end{array}$ & $\begin{array}{c}\text { Marine } \\
\text { environment }\end{array}$ \\
\hline $\begin{array}{l}\text { Optimal temperature } \\
\left({ }^{\circ} \mathrm{C}\right)\end{array}$ & 33.8 & 30 & 35 & 22 & 30 & 30 & 20 & 37 \\
\hline Catalase & - & + & + & - & - & + & + & + \\
\hline \multicolumn{9}{|l|}{ Utilization of: } \\
\hline Arabinose & - & $+^{*}$ & + & - & $+^{*}$ & - & - & - \\
\hline Cellobiose & - & $+^{*}$ & + & + & $+^{*}$ & + & - & $\mathrm{ND}$ \\
\hline Fructose & - & $+^{*}$ & - & - & $+^{*}$ & + & - & ND \\
\hline Galactose & + & $-{ }^{*}$ & + & + & $+^{*}$ & + & - & $\mathrm{ND}$ \\
\hline Gelatin & + & $\mathrm{ND}$ & - & + & $-{ }^{*}$ & + & + & + \\
\hline Glycerol & + & $-*$ & - & - & $-*$ & - & - & - \\
\hline Glycogen & - & $+^{*}$ & + & $\mathrm{ND}$ & $-{ }^{*}$ & + & $\mathrm{ND}$ & $\mathrm{ND}$ \\
\hline Lactose & + & $+^{*}$ & - & + & $-{ }^{*}$ & + & - & $\mathrm{ND}$ \\
\hline Maltose & + & $+^{*}$ & + & + & $+^{*}$ & + & - & - \\
\hline Mannose & - & $+^{*}$ & + & + & $+^{*}$ & $\mathrm{~W}$ & - & - \\
\hline Trehalose & - & $-*$ & + & + & $-*$ & + & - & ND \\
\hline Turanose & - & $-{ }^{*}$ & $\mathrm{ND}$ & + & $+^{*}$ & + & $\mathrm{ND}$ & - \\
\hline Xylose & - & $+^{*}$ & + & + & $+^{*}$ & ND & $\mathrm{ND}$ & - \\
\hline $\begin{array}{l}\text { Fermentation end } \\
\text { products from } \\
\text { glucose } \dagger\end{array}$ & A, P & $\mathrm{A}, \mathrm{P}, \mathrm{S}$ & $\mathrm{ND}$ & - & $\mathrm{A}, \mathrm{P}, \mathrm{S}$ & - & - & - \\
\hline $\begin{array}{l}\text { DNA G + C content } \\
(\mathrm{mol} \%)\end{array}$ & 45 & 39 & 44.3 & 44.9 & 39.3 & 34.5 & $38-39$ & $43-45$ \\
\hline
\end{tabular}

${ }^{\star}$ Data from this study.

$\dagger$ A, Acetate; P, propionate; s, succinate.

Gram-negative, oxidase-positive and catalase-negative. Cells are filamentous. Facultatively anaerobic, chemoorganotrophic and moderately halophilic. Ferment sugars. Cellular fatty acids are dominated by saturated isobranched fatty acids. Possesses menaquinone MK-7 as the major respiratory quinone. Acetate and propionate are produced as major fermentation products from glucose. According to the $16 \mathrm{~S}$ rRNA gene sequence of the type strain of the type species, the genus belongs to the phylum Bacteroidetes. The only known strain was isolated from tidal flat sediment. The DNA $\mathrm{G}+\mathrm{C}$ content of the type strain of the type species is $45 \mathrm{~mol} \%$. The type species is Marinifilum fragile.

\section{Description of Marinifilum fragile sp. nov.}

Marinifilum fragile (fra'gi.le. L. neut. adj. fragile fragile).

Displays the following properties in addition to those given in the genus description. Cells are initially filamentous, becoming spherical in aged cultures. Filaments are generally $0.5 \mu \mathrm{m}$ wide and variable in length, with a 0.3 $3.8 \mu \mathrm{m}$ long flagella-like structure at the end. Heat sensitive. Colonies on MA are circular, in some cases with erose edges, and ivory or brownish ivory coloured. Growth occurs at $\mathrm{pH}$ 6-8 (optimum $\mathrm{pH} 7$ ) and $20-37.4{ }^{\circ} \mathrm{C}$ (optimum $33{ }^{\circ} \mathrm{C}$ ). Requires artificial $1-7 \%(\mathrm{w} / \mathrm{v})$ sea salts (optimum 3\%). Does not grow with 0-9\% (w/v) $\mathrm{NaCl}$ alone. Utilizes glycerol, galactose, glucose, $\mathrm{N}$-acetylglucosamine, maltose, lactose, melibiose and starch, but not turanose, D-xylose, fructose, gentiobiose, glycogen, mannose or mannitol. Produces $\beta$-galactosidase, gelatinase, alkaline phosphatase, trypsin, acid phosphatase and $N$ acetyl- $\beta$-glucosaminidase. Nitrate is reduced to nitrite. Indole is produced, but $\mathrm{H}_{2} \mathrm{~S}$ is not. The major fatty acid is iso- $\mathrm{C}_{15: 0}$.

The type strain is $\mathrm{JC} 469^{\mathrm{T}}$ (=IMSNU $14138^{\mathrm{T}}=\mathrm{KCTC}$ $22488^{\mathrm{T}}=\mathrm{JCM} 15579^{\mathrm{T}}$ ), isolated from tidal flat sediment of Yeocha, Ganghwa Island, South Korea. 
Table 2. Cellular fatty acid composition of strain $\mathrm{JC} 2469^{\top}$ and its phylogenetic neighbours

Strains: 1, Marinifilum fragile gen. nov., sp. nov. JC2469 ${ }^{\mathrm{T}}$ (data from this study); 2, Cytophaga fermentans KCTC 2901 ${ }^{\mathrm{T}}$ (this study); 3 , Alkaliflexus imshenetskii DSM $15055^{\mathrm{T}}$ (Zhilina et al., 2004); 4, Prolixibacter bellariivorans JCM $13498^{\mathrm{T}}$ (Holmes et al., 2007); 5, Paludibacter propionicigenes JCM $13257^{\mathrm{T}}$ (Ueki et al., 2006); 6, Zhouia amylolytica JCM $14016^{\mathrm{T}}$ (Liu et al., 2006); 7, Aequorivita antarctica DSM 14231 ${ }^{\mathrm{T}}$ (Bowman \& Nichols, 2002); 8 , Actibacter sediminis JCM $14002^{\mathrm{T}}$ (Kim et al., 2008). Only fatty acids representing at least $1 \%$ of the total fatty acids for at least one of the strains are shown. - , Not detected/not reported.

\begin{tabular}{|c|c|c|c|c|c|c|c|c|}
\hline Fatty acid (\%) & 1 & 2 & 3 & 4 & 5 & 6 & 7 & 8 \\
\hline iso- $\mathrm{C}_{13: 0}$ & 4.4 & - & 1.4 & 0.1 & 0.3 & - & - & 6.4 \\
\hline iso- $\mathrm{C}_{14: 0}$ & 0.5 & - & 1.1 & 2.5 & 0.3 & - & 0.2 & - \\
\hline $\mathrm{C}_{15: 0}$ & 0.1 & 0.5 & 39.0 & 20.7 & 19.0 & 9.4 & 0.6 & - \\
\hline anteiso- $\mathrm{C}_{15: 0}$ & 3.5 & - & 11.6 & 23.3 & 30.8 & 1.1 & 15.7 & 3.7 \\
\hline iso- $\mathrm{C}_{15: 0} 3-\mathrm{OH}$ & 9.1 & - & - & - & 1.1 & 3.9 & 5.4 & - \\
\hline $\mathrm{C}_{15: 0} 3-\mathrm{OH}$ & - & - & 2.4 & 0.5 & 2.6 & - & - & 2.1 \\
\hline $\mathrm{C}_{16: 0}$ & 0.3 & 18.0 & 1.0 & 5.6 & 4.9 & 4.9 & 1.9 & - \\
\hline anteiso- $\mathrm{C}_{17: 0} 3-\mathrm{OH}$ & - & - & - & - & 17.9 & - & 2.9 & - \\
\hline iso- $\mathrm{C}_{17: 0} 3-\mathrm{OH}$ & 7.0 & - & - & - & 6.2 & - & 2.0 & 13.7 \\
\hline $\mathrm{C}_{18: 1} \omega 7 c$ & - & 12.5 & - & - & - & - & - & - \\
\hline
\end{tabular}

${ }^{\star}$ Summed features are groups of two or three fatty acids that cannot be separated by GC with the MIDI system. Summed feature 3 contained $\mathrm{C}_{16: 1} \omega 7 c$ and/or iso- $\mathrm{C}_{15: 0} 2-\mathrm{OH}$.

\section{Acknowledgements}

We are grateful to Professor Dr Bernhard Schink for help with nomenclature. This work was supported by the Korea Ministry of Education, Science and Technology under the National Research Laboratory Program (M10500000110-05J0000-11010).

\section{References}

Altschul, S. F., Madden, T. L., Schäffer, A. A., Zhang, J., Zhang, Z., Miller, W. \& Lipman, D. J. (1997). Gapped BLAST and PSI-BLAST: a new generation of protein database search programs. Nucleic Acids Res 25, 3389-3402.

Bowman, J. P. \& Nichols, D. S. (2002). Aequorivita gen. nov., a member of the family Flavobacteriaceae isolated from terrestrial and marine Antarctic habitats. Int J Syst Evol Microbiol 52, 1533-1541.

Chun, J. \& Goodfellow, M. (1995). A phylogenetic analysis of the genus Nocardia with 16S rRNA gene sequences. Int J Syst Bacteriol 45, 240-245.

Chun, J., Lee, J.-H., Jung, Y., Kim, M., Kim, S., Kim, B. K. \& Lim, Y. W. (2007). EzTaxon: a web-based tool for the identification of prokaryotes based on $16 \mathrm{~S}$ ribosomal RNA gene sequences. Int J Syst Evol Microbiol 57, 2259-2261.

Collins, M. D. (1985). Analysis of isoprenoid quinones. Methods Microbiol 18, 329-366.

Felsenstein, J. (1981). Evolutionary trees from DNA sequences: a maximum likelihood approach. J Mol Evol 17, 368-376.

Felsenstein, J. (1985). Confidence limits on phylogenies: an approach using the bootstrap. Evolution 39, 783-791.

Fitch, W. M. (1971). Toward defining the course of evolution: minimum change for a specific tree topology. Syst Zool 20, 406-416.
Fitch, W. M. \& Margoliash, E. (1967). Construction of phylogenetic trees. Science 155, 279-284.

Holmes, D. E., Nevin, K. P., Woodard, T. L., Peacock, A. D. \& Lovley, D. R. (2007). Prolixibacter bellariivorans gen. nov., sp. nov., a sugarfermenting, psychrotolerant anaerobe of the phylum Bacteroidetes, isolated from a marine-sediment fuel cell. Int J Syst Evol Microbiol 57, 701-707.

Jeon, Y. S., Chung, H., Park, S., Hur, I., Lee, J. H. \& Chun, J. (2005). jPHYDIT: a JAVA-based integrated environment for molecular phylogeny of ribosomal RNA sequences. Bioinformatics 21, 3171-3173.

Jukes, T. H. \& Cantor, C. R. (1969). Evolution of protein molecules. In Mammalian Protein Metabolism, vol. 3, pp. 21-132. Edited by H. N. Munro. New York: Academic Press.

Kim, B. S., Oh, H. M., Kang, H., Park, S. S. \& Chun, J. (2004). Remarkable bacterial diversity in the tidal flat sediment as revealed by $16 \mathrm{~S}$ rDNA analysis. J Microbiol Biotechnol 14, 205-211.

Kim, B. S., Oh, H. M., Kang, H. \& Chun, J. (2005). Archaeal diversity in tidal flat sediment as revealed by $16 \mathrm{~S}$ rDNA analysis. J Microbiol 43, 144-151.

Kim, S., Jeong, H. \& Chun, J. (2007). Clostridium aestuarii sp. nov., from tidal flat sediment. Int J Syst Evol Microbiol 57, 1315-1317.

Kim, J. H., Kim, K. Y., Hahm, Y. T., Kim, B. S., Chun, J. \& Cha, C. J. (2008). Actibacter sediminis gen. nov., sp. nov., a marine bacterium of the family Flavobacteriaceae isolated from tidal flat sediment. Int J Syst Evol Microbiol 58, 139-143.

Kovács, N. (1956). Identification of Pseudomonas pyocyanea by the oxidase reaction. Nature 178, 703.

Liu, Z. P., Wang, B. J., Dai, X., Liu, X. Y. \& Liu, S. J. (2006). Zhouia amylolytica gen. nov., sp. nov., a novel member of the family Flavobacteriaceae isolated from sediment of the South China Sea. Int J Syst Evol Microbiol 56, 2825-2829. 
Mesbah, M. \& Whitman, W. B. (1989). Measurement of deoxyguanosine/thymidine ratios in complex mixtures by high-performance liquid chromatography for determination of the mole percentage guanine + cytosine of DNA. J Chromatogr 479, 297-306.

Minnikin, D. E., O'Donnell, A. G., Goodfellow, M., Alderson, G., Athalye, M., Schaal, A. \& Parlett, J. H. (1984). An integrated procedure for the extraction of bacterial isoprenoid quinones and polar lipids. J Microbiol Methods 2, 233-241.

Nakagawa, Y. \& Yamasato, K. (1993). Phylogenetic diversity of the genus Cytophaga revealed by $16 \mathrm{~S}$ rRNA sequencing and menaquinone analysis. J Gen Microbiol 139, 1155-1161.

Pearson, W. R. \& Lipman, D. J. (1988). Improved tools for biological sequence comparison. Proc Natl Acad Sci U S A 85, 2444-2448.

Powers, E. M. (1995). Efficacy of the Ryu nonstaining KOH technique for rapidly determining gram reactions of food-borne and waterborne bacteria and yeasts. Appl Environ Microbiol 61, 3756-3758.

Reichenbach, H. (1989). Genus I. Cytophaga Winogradsky 1929, $577^{\mathrm{AL}}$ emend. In Bergey's Manual of Systematic Bacteriology, vol. 3, pp. 2015-2050. Edited by J. T. Staley, M. P. Bryant, N. Pfenning \& J. G. Holt. Baltimore: Williams \& Wilkins.
Saitou, N. \& Nei, M. (1987). The neighbor-joining method: a new method for reconstructing phylogenetic trees. Mol Biol Evol 4, 406-425.

Swofford, D. L. (1998). PAUP*: phylogenetic analysis using parsimony ( ${ }^{*}$ and other methods), version 4. Sunderland, MA: Sinauer Associates.

Ueki, A., Akasaka, H., Suzuki, D. \& Ueki, K. (2006). Paludibacter propionicigenes gen. nov., sp. nov., a novel strictly anaerobic, Gramnegative, propionate-producing bacterium isolated from plant residue in irrigated rice-field soil in Japan. Int J Syst Evol Microbiol 56, 39-44.

Wise, M. G., McArthur, J. V. \& Shimkets, L. J. (2001). Methylosarcina fibrata gen. nov., sp. nov. and Methylosarcina quisquiliarum sp. nov., novel type 1 methanotrophs. Int J Syst Evol Microbiol 51, 611-621.

Yi, H. \& Chun, J. (2006a). Thalassobius aestuarii sp. nov., isolated from tidal flat sediment. J Microbiol 44, 171-176.

Yi, H. \& Chun, J. (2006b). Flavobacterium weaverense sp. nov. and Flavobacterium segetis sp. nov., novel psychrophiles isolated from the Antarctic. Int J Syst Evol Microbiol 56, 1239-1244.

Zhilina, T. N., Appel, R., Probian, C., Brossa, E. L., Harder, J., Widdel, F. \& Zavarzin, G. A. (2004). Alkaliflexus imshenetskii gen. nov., sp. nov., a new alkaliphilic gliding carbohydrate-fermenting bacterium with propionate formation from a soda lake. Arch Microbiol 182, 244-253. 